\title{
CURRENT STATE AND TERRITORIAL PATTERNS OF TOURISM DEVELOPMENT IN ITALY
}

\author{
Andrii MAISTER \\ Lutsk Institute of Human Development of University "Ukraine", Lutsk, Ukraine \\ maister89@ukr.net
}

\begin{abstract}
Tourism is a profitable sector of the economy, which, despite all current challenges, is rapidly developing and prioritized for the development of economic, social and cultural realms in many countries. Leading positions in international tourism are occupied by European countries, in particular Italy. The article analyzes the current state and territorial features of tourism development in Italy, considering natural, historical and cultural tourist recourses and country hotel fund. The analysis bases on such key indicators as the tourism contribution to gross domestic product, the tourism contribution to employment, the tourism capital investments, the tourism inbound (foreign) and outbound (abroad) volume, the international tourism receipts. The geographical structure of tourist flows in Italy is considered. The country has a considerable territorial differentiation in terms of tourism development. An integral index was calculated for Italy regions to evaluate tourism development level with subsequent classification of regions according to this indicator. The calculated indices allowed delimiting of the six groups of regions with high, higher than average, medium, lower than average, low and very low tourism development levels respectively. The features of tourism development in the regions of each group are revealed. In particular, the highest intensity of tourist arrivals is observed in the alpine regions of the country, which specialize in ski tourism. The high level of tourism development is also typical for the northern and central regions of the country. The lowest intensity of tourism is observed in the south-eastern regions of the country. In general, contemporary tourist development of the country is characterized with annual growth in the number of tourist arrivals, significant revenues from the tourism industry, positive balance of tourist flows, high share of tourism in the country's GDP, formation of world-famous centers of tourism, high tourist rates. All this indicates that Italy remains one of the tourism leaders in the international tourism market.
\end{abstract}

Key words: tourism, tourism development, tourist flows, tourism development level, Italy regions, Italy.

DOI: https://doi.org/10.17721/2413-7154/2020.83.37-45

UDC: $379.85(450)$

Received: March 11, 2020.

Revised: April 15, 2020.

Accepted: May 4, 2020.

\section{СУЧАСНИЙ СТАН I ТЕРИТОРІАЛЬНІ ОСОБЛИВОСТІ РОЗВИТКУ ТУРИЗМУ В ІТАЛІЇ}

\author{
Андрій МАЙСТЕР \\ Луцький інститут розвитку людини Університету «Україна», Луцьк, Україна \\ maister89@ukr.net
}

\begin{abstract}
Анотація: У статті здійснено аналіз сучасного стану і територіальних особливостей розвитку туризму в Італії. Розглянуто природні, історико-культурні туристичні ресурси та готельний фонд країни. Проаналізовано такі ключові показники, як внесок туризму у валовий внутрішній продукт, капітальні інвестиції в туризмі, внесок туристичної галузі в зайнятість населення, обсяги в'їзного (іноземного) та виїзного (зарубіжного) туризму, доходи від міжнародного туризму. Розглянуто географічну структуру туристичних потоків Італії. За результатами проведеної оцінки рівнів туристичного розвитку регіонів Італії встановлено, що країна має значну територіальну диференціацію розвитку туризму. Розраховано інтегральний індекс рівня туристичного розвитку регіонів Італії та проведено їх групування за цим показником. За індексом рівня виділено шість груп регіонів: із високим, вищим від середнього, середнім, нижчим від середнього, низьким і дуже низьким рівнем розвитку туризму. Виявлено особливості розвитку туризму в регіонах кожної групи.
\end{abstract}

Ключові слова: туризм, туристичний розвиток, туристичні потоки, рівень розвитку туризму, регіони Італії, Італія. 
Постановка проблеми. Туризм є прибутковою галуззю економіки, яка стрімко розвивається i $\epsilon$ пріоритетом для розвитку економічної, соціальної та культурної сфер життя багатьох країн світу. Соціально-економічне значення туризму в сучасних умовах визначається тим, що туристичний бізнес сприяє розвитку економіки, розвиваючи такі галузі, як сільське господарство, торгівля, будівництво, зв'язок тощо, сприяє зайнятості населення, зростанню валового внутрішнього продукту (ВВП), є вагомим джерелом валютних надходжень країни.

Сучасний розвиток світової туристичної сфери характеризується певними територіальними диспропорціями. Провідні позиції у міжнародному туризмі займають країни Європи, зокрема Італія. Туризм в Італії є важливою сферою економіки. Країна $€$ центром міжнародного туризму. За індексом туристичної конкурентоспроможності Італія займає восьме місце в світі (2019 р.) (The Travel \& Tourism Competitiveness Report, 2020). Зважаючи на це, досвід Італії у сфері туризму може бути корисним для України.

Аналіз останніх досліджень і публікацій. Туристична проблематика Італії досліджена в працях багатьох українських учених. Проте більшість досліджень мають загальний характер, без глибокого аналізу внутрішніх відмінностей розвитку туризму в країні. Дослідженням туристичних ресурсів, сучасного стану, проблем та перспектив розвитку туризму в Італії займалися М. В. Клапчук (Klapchuk, 2017), В. В. Смаль (Smal, 2013), Г. П. Щука (Schuka, 2010). Аналіз окремих видів розвитку туризму в Італії знаходимо в працях В. В. Безуглого (Bezuhlyi, 2011), В. О. Патійчука (Patiychuk, 2016; Patiychuk \& Lukashuk, 2017). Готельна індустрія Італії досліджувалася Я. Є. Гончаренко й О. В. Шикіною (Honcharenko \& Shykina, 2018). Регіональні туристичні системи Італії проаналізовано П. В. Доаном (Doan, 2014). Італія є об'єктом дослідження багатьох закордонних науковців, таких як А. I. Зирянок й I. С. Зирянова (2016), I. К. Чемакін (2017), I. В. Шахнович (Shahnovich, 2015), Ю. В. Юнах (Yunah, 2015), А. Berrino (2011), A. Jelardi (2012) та ін.

Мета та завдання статті. Метою дослідження $€$ аналіз розвитку туризму в Італії та виявлення його територіальних особливостей. $\mathrm{У}$ процесі дослідження вирішувалися такі завдання: здійснити аналіз туристичних ресурсів Італії; проаналізувати сучасний стан розвитку туризму в країні; провести оцінку рівня туристичного розвитку регіонів Італії; виділити групи регіонів Італії за показником індексу рівня туристичного розвитку; проаналізувати територіальні відмінності розвитку туризму в країні.

Методика дослідження. Для визначення рівня туристичного розвитку регіонів Італії використано усереднений синтетичний показник, отриманий за агломеративно-ієрархічною процедурою стандартизації, який часто використовують під час класифікації географічних об’єктів. Процедуру стандартизації різнойменних показників здійснено за формулою:

$$
\begin{aligned}
\bar{X}_{j} & =\frac{\left|x_{j}-\tilde{x}_{j}\right|}{\left|\max / \min x_{j}-\tilde{x}_{j}\right|}, \\
i & =1,2,3, \ldots, \mathrm{n} ; \mathrm{j}=1,2,3, \ldots, \mathrm{m} .
\end{aligned}
$$

де $\bar{X}_{i j}$ - нормоване значення показника;

$x_{i j}$ - часткові показники туристичної діяльності;

$\widetilde{x}_{j}-$ найгірші значення по кожному показнику 3 усіх взятих для розрахунків; $\max / \min x_{j}$ - найбільш відмінні від $\tilde{x}_{j}$ значення показників;

$n$-кількість досліджуваних територіальних одиниць;

$m$ - кількість показників, узятих для розрахунків.

На основі сумування отриманих стандартизованих значень вихідних показників $X_{i j}$ та визначення ï середньозваженого стандартизованого значення отримано інтегральний параметр $I_{t}$, який може бути оцінений як індекс рівня туристичного розвитку окремої адміністративної одиниці. Розрахунок інтегрального індексу рівня туристичного розвитку регіону $(I)$ здійснювався за такою формулою:

$I_{t}=\frac{\sum \bar{X}_{i j}}{n}$,

де $I_{t}$ - інтегральний індекс рівня туристичного розвитку $j-i ̈$ адміністративної одиниці країни;

$\bar{X}_{i j}-$ нормований показник туристичної діяльності $j$-ї адміністративної одиниці країни;

$n$ - кількість показників, що використовуються для оцінювання рівня туристичного розвитку.

Величина індексу $I_{t}$ коливається від 0 до $1 \mathrm{i} \epsilon$ безрозмірною величиною, яка виражає кумулятивний ефект урахування різноманітних часткових показників, узятих для розрахунку.

Для визначення інтегрального індексу рівня туристичного розвитку регіонів Італії взято вихідні часткові показники за 2018 р., які відображають як абсолютні параметри розвитку туризму, так i відносні. Для розрахунку залучено 11 абсолютних і відносних показників: 1) кількість колективних засобів розміщення; 2) територіальна концентрація колективних засобів розміщення; 3) кількість колективних засобів розміщення на 10000 осіб; 4) кількість місць у колективних засобах розміщення; 5) кількість місць у колективних засобах розміщення на 10000 осіб; 6) коефіцієнт завантаженості закладів розміщення; 7) коефіцієнт використання спальних місць у закладах розміщення; 8) кількість прибуттів у колективні засоби розміщення; 9) кількість ночівель у колективних засобах розміщення; 10) щільність туризму (кількість ночівель/км²); 11) інтенсивність туризму (кількість ночівель/1000 осіб). 
Виклад основного матеріалу. Італія держава на півдні Європи, розміщена в центрі Середземномор'я. Столиця країни - м. Рим. Загальна площа Італії, у тому числі о. Сицилія, Сардинія та інші острови, становить 301,3 тис. км². Чисельність населення країни оцінюється у 60,4 млн осіб (2018 p.) (Istituto Nazionale di Statistica, 2020). Італія має вигідне географічне положення: на перехресті торгових шляхів між Заходом та Сходом, що значною мірою сприяє розвитку ділового туризму. Країна омивається водами п'яти морів: Середземного, Тірренського, Лігурійського, Адріатичного та Іонічного. Кордони з високорозвинутими країнами (Швейцарія, Австрія, Словенія, Франція) визначають географію потоків в'їзного та виїзного туризму між Італією та сусідніми країнами.

Італія має багаті високоякісні природні й історично-культурні ресурси, які формують потужну базу для розвитку туризму. У країні наявні сприятливі природні умови, що зумовлено значною протяжністю країни $з$ півночі на південь. Природно-рекреаційні ресурси Італії сприяють розвитку туризму. Клімат м'який, субтропічний середземноморський. Рельєф включає рівнинні (Паданська рівнина) й гірські (Альпи, Апенніни) природні ландшафти, які сприятимуть розвитку різних видів туризму. Відпочинок на узбережжі озер (Комо, Гарда, ЛагоМаджоре), де розміщені численні готелі, кемпінги, пансіони, національні парки (Стельвіо Борміо, ГранПарадізо) дає змогу спостерігати за тваринами в їх природному середовищі (Yunah, 2015).

Історико-культурний потенціал Італії охоплює різні за цінністю пам'ятки - місцеві, регіональні, загальнодержавні, світові. Найвідомішими історикокультурними пам'ятками країни вважаються Тріумфальна арка Тіта (81 р. н. е.), Колона Трояна (111-114 pp.), Колізей (75-80 pp.), Пантеон (125 р. н. е.), Терми Каракали в Римі (125 р. н. е.), театр «Ла-Скала» (XVI ст.), церква Сант-Амброджо (IX-XV ст.), замок Кастелло Сфорцеско (1450р.), монастир Санта-Марія деле Грація (XV ст.) у Мілані, Руїни давнього міста Помпеї на південному сході від Неаполя (зруйноване у 79 р. н. е.), замок Кастель дель Ово (ХІІ ст.), монастир Чиртоза ді Сан-Мартіно (XIV-XVII ст.) в Неаполі, церква Сан-Лоренцо (XVII ст.), палаци Коріньяно (XV-XVII ст.) в Турині та ін. Серед історичних культурних закладів сучасності особливе значення мають найстаріший в Свропі Болонський університет (XII ст.), картинні галереї Пітті (XVI ст.) та Уффіці (XVI ст.) у Флоренції та ін. (Bezuhlyi, 2011, p. 45).

Більшість туристів, які відвідують Італію, перш за все, прагнуть ознайомитися з об’єктами світової спадщини ЮНЕСКО. Станом на 2019 р. до списку світової спадщини ЮНЕСКО на території Італії належить 55 об'єктів (4,7 \% від загальної кількості у світі). Разом з Китаєм, Італія займає перше місце в світі за кількістю об'єктів світової спадщини (World Heritage List Statistics, 2020).

Важливою складовою успішного розвитку туризму в Італії є також готельний фонд. Італійські готелі вирізняються своєю самобутністю, середземноморським колоритом, смаком у дизайні номерів. У 2018 р. в Італії нараховувалося 216141 колективний засіб розміщення, включаючи готелі, кемпінги, оздоровчі парки та ін. Італійська система готелів пропонує туристичному ринку 32898 готелів та аналогічних засобів розміщення, які мають у своєму розпорядженні 2,3 млн місць (Capacity of collective accommodation establishments and occupancy in collective accommodation establishments, 2020). Коефіцієнт завантаженості колективних засобів розміщення Італії становить $51 \%$.

Італія займає провідне місце в міжнародному туризмі, адже є однією із найбільш відвідуваних країн не лише Європи, а й усього світу. Характерною рисою розвитку туризму в Італії $\epsilon$ те, що країна близько розміщена до основних туристичних ринків, має розвинену туристичну інфраструктуру. Сусідське положення із Західноєвропейським, Центрально-Східноєвропейським туристичними районами, близьке розміщення до Близькосхідного й Африканського туристичних регіонів $€$ надзвичайно важливим, адже основні туристичні потоки до Італії спрямовані саме з цих країн (Ahafonova \& Ahafonova, 2002, p. 158).

Туризм має відчутний вплив на економіку Італії. У 2018 р. прямий внесок туризму у ВВП країни становив 117 млрд дол. США (5,6 \% ВВП країни) і збільшився на 9,3 \% відносно 2017 р. За цим показником країна займає п’яте місце у світі після США, Китаю, Німеччини та Японії. Загальний внесок туристичної галузі у ВВП Італії у 2018 р. склав 274,9 млрд дол. США або 13,2 \% ВВП країни (World Travel and Tourism, 2020). Як прямий, так і загальний внески туризму у ВВП країни упродовж 2008-2018 pp. мали тенденцію до спадів та зростання. Протягом 2015-2018 pр. спостерігається стійке зростання частки туризму у ВВП країни (рис. 1).

Туризм має позитивний вплив на ринок праці Італії. Так, у туристичній сфері країни зайнято 1,5 млн осіб (2018р.), а загальний внесок туризму в зайнятість населення становить 3,5 млн осіб (2018р.) (World Travel and Tourism, 2020). 32011 р. відбувається стійке зростання зайнятості населення у туристичній сфері країни.

Для ефективного розвитку галузей економіки, у тому числі туризму, важливим є інвестування. У 2018 р. обсяг капітальних інвестицій у туристичній сфері Італії становив 11,4 млрд дол. США і збільшився на $12 \%$ порівняно з 2017 р. За цим показником країна посідає шосте місце в Європі та 19-те - у світі (World Travel and Tourism, 2020).

За кількістю міжнародних туристичних прибуттів Італія займає п'яте місце у світі після Франції, Іспанії, США та Китаю. У 2018 р. Італію відвідали 61,6 млн іноземних туристів, що більше на 3,3 млн, ніж у 2017 р. Кількість туристичних прибуттів зросла з 41,1 млн у 2006 р. до 61,6 млн осіб у 2018 р., зростаючи щорічно у середньому на $3 \%$ (рис. 2). Загальний тренд іноземних туристичних потоків до Італії упродовж 2006-2018 рр. можна описати поліноміальною моделлю другої степені при дуже високому коефіцієнті детермінації $\left(\mathrm{R}^{2}=0,97\right)$ (рис. 2). 


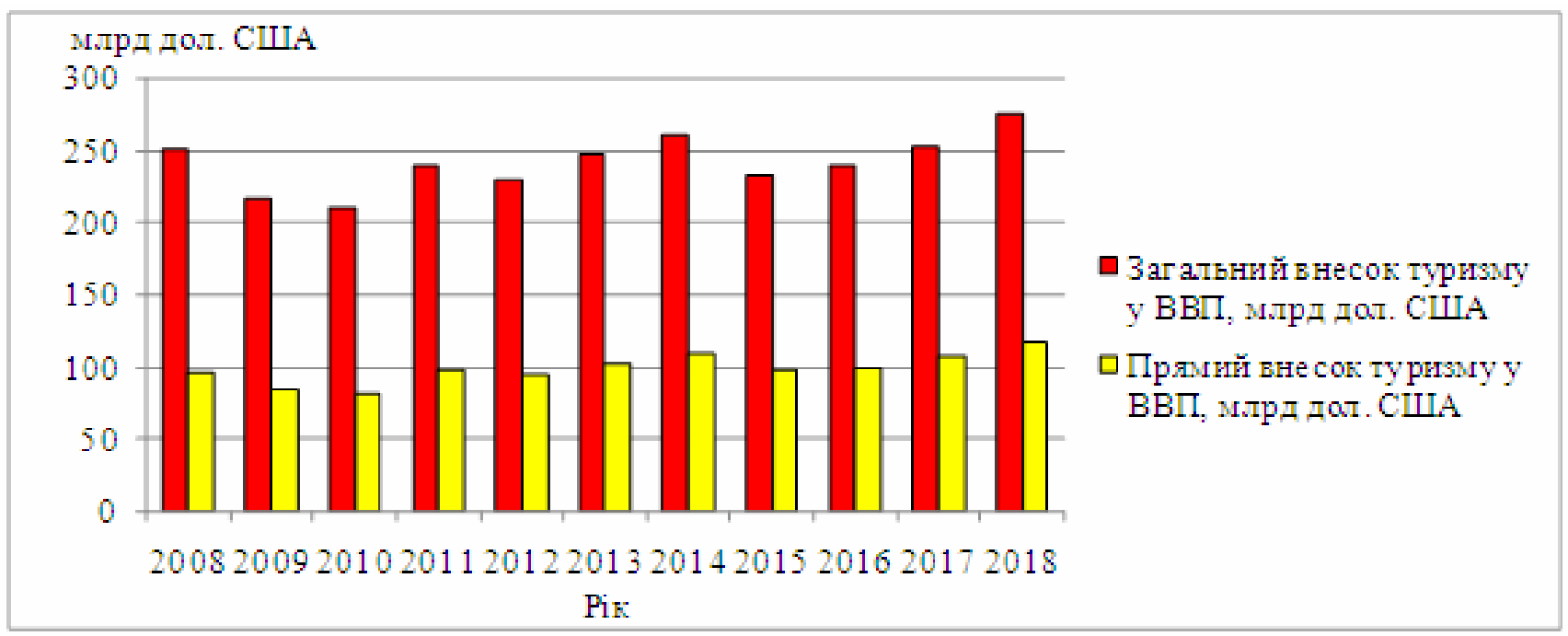

Рис. 1. Внесок туризму у ВВП Італії у 2008-2018 рр. Складено за: (World Development Indicators, 2020).

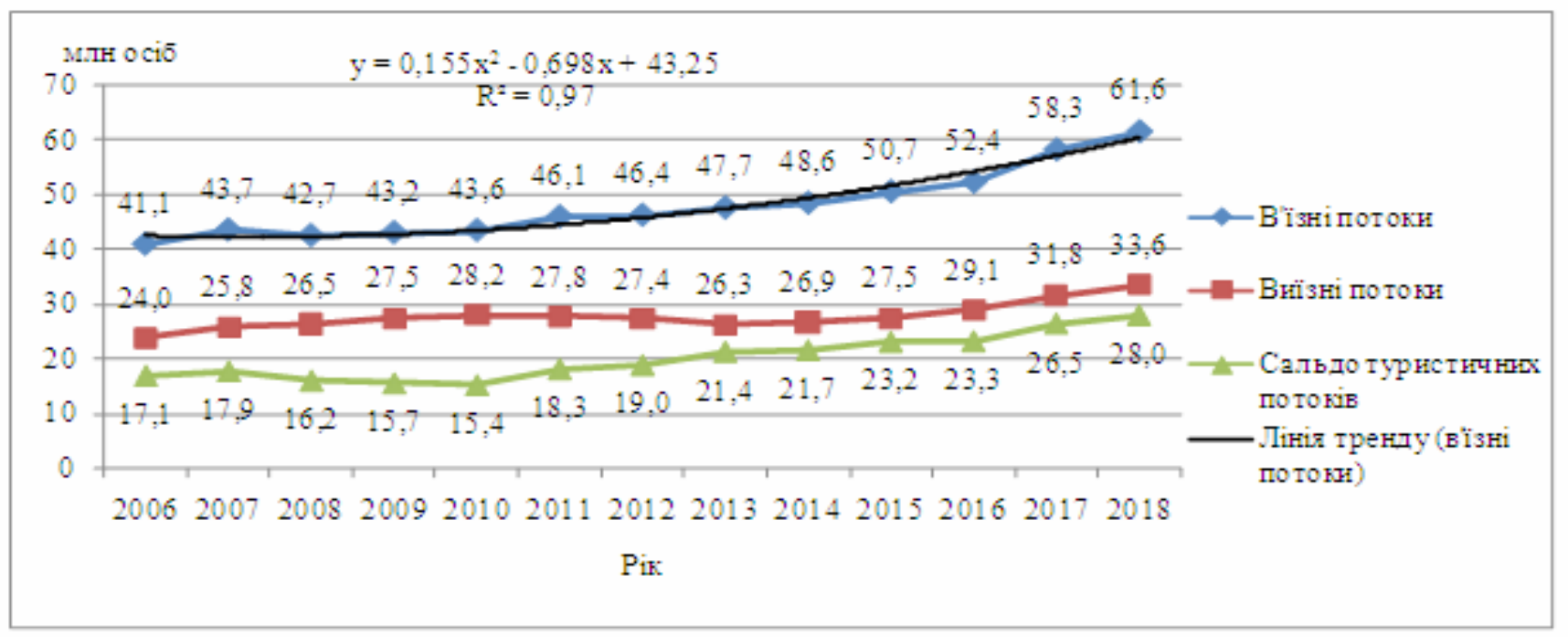

Рис. 2. Туристичні потоки Італії у 2006-2018 рр. Складено за: (Italy. Tourism, 2020).

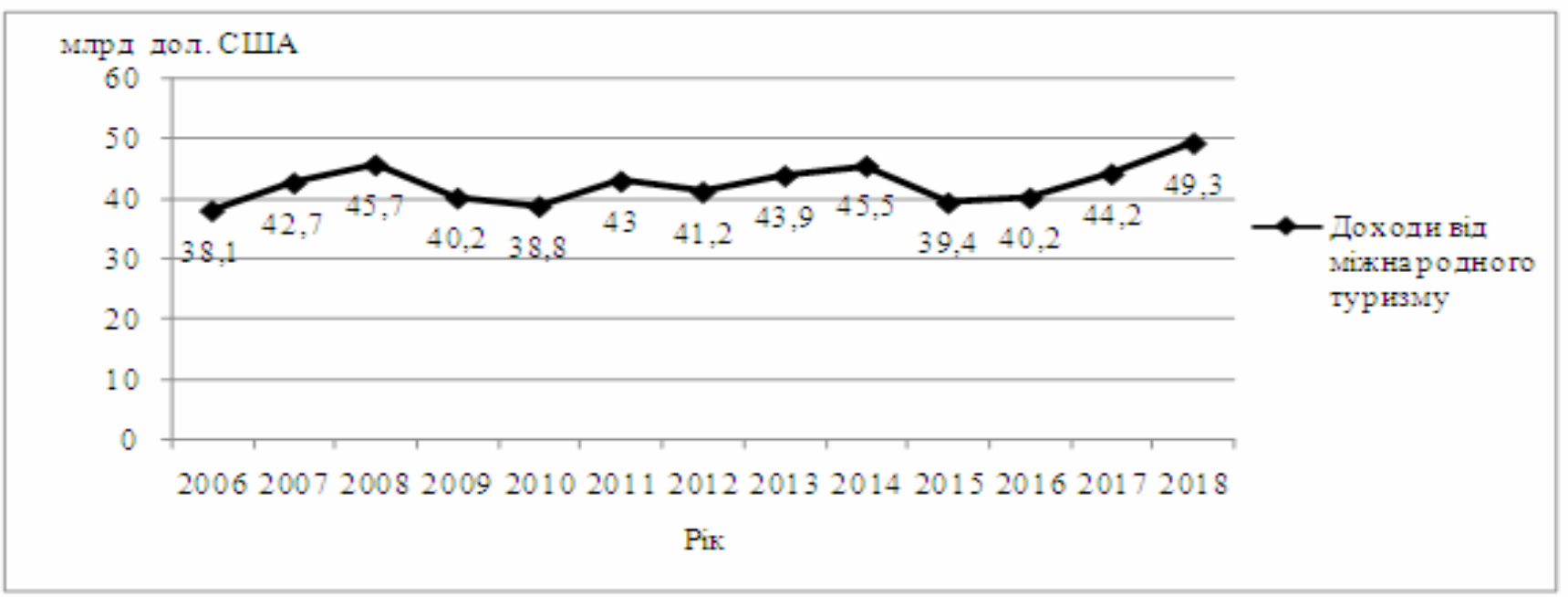

Рис. 3. Доходи від міжнародного туризму Італії у 2006-2018 рр. Складено за: (World Development Indicators, 2020). 
Таблицяя 1

Показники розвитку туризму в регіонах Італії у 2018 р.*

\begin{tabular}{|c|c|c|c|}
\hline Макрорегіон/Регіон & $\begin{array}{c}\text { Загальна кількість } \\
\text { туристичних прибуттів } \\
\text { у колективні заклади } \\
\text { розміщення, } \\
\text { одиниць }\end{array}$ & $\begin{array}{c}\text { Коефіцієнт } \\
\text { завантаженості } \\
\text { колективних закладів } \\
\text { розміщення, \% }\end{array}$ & $\begin{array}{c}\text { Інтегральний } \\
\text { індекс рівня } \\
\text { туристичного } \\
\text { розвитку, } I_{t}\end{array}$ \\
\hline Північно-Західна Італія & 28006768 & 48,7 & $0,341^{1}$ \\
\hline П'ємонт & 5276117 & 47,3 & 0,271 \\
\hline Валле-д’Аоста & 1254191 & 50,8 & 0,342 \\
\hline Лігурія & 4718832 & 45,7 & 0,333 \\
\hline Ломбардія & 16757628 & 50,1 & 0,417 \\
\hline Північно-Східна Італія & 45557719 & 59,3 & $0,566^{1}$ \\
\hline Трентіно-Альто-Адідже & 11925777 & 64,8 & 0,628 \\
\hline Венето & 19563348 & 60,2 & 0,886 \\
\hline Фріулі-Венеція-Джулія & 2610097 & 38,5 & 0,272 \\
\hline Емілія-Романья & 11458497 & 55,9 & 0,478 \\
\hline Центральна Італія & 31457047 & 49,2 & $0,365^{1}$ \\
\hline Тоскана & 14188009 & 47,1 & 0,471 \\
\hline Умбрія & 2436857 & 36,8 & 0,206 \\
\hline Марке & 2256564 & 45,5 & 0,293 \\
\hline Лаціо & 12575617 & 54,6 & 0,490 \\
\hline Південна Італія & 14800449 & 42,7 & $\mathbf{0 , 2 1 7 ^ { 1 }}$ \\
\hline Абруццо & 1643087 & 37,0 & 0,181 \\
\hline Молізе & 138570 & 44,6 & 0,169 \\
\hline Кампанія & 6234863 & 62,5 & 0,394 \\
\hline Апулія & 4065979 & 34,8 & 0,22 \\
\hline Базиліката & 892087 & 41,9 & 0,174 \\
\hline Калабрія & 1825863 & 31,2 & 0,163 \\
\hline Острівна Італія & 8278949 & 45,3 & $0,265^{1}$ \\
\hline Сицилія & 4998055 & 41,8 & 0,239 \\
\hline Сардинія & 3280894 & 49,9 & 0,291 \\
\hline Загалом & 128100932 & 51,0 & $0,346^{1}$ \\
\hline
\end{tabular}

*Розраховано за: (Eurostat, 2020).

'Розраховано як середнє значення за областями макрорегіону/країни

У 2018 р. кількість міжнародних (виїзних) туристів з Італії становила 33,6 млн осіб, що більше на 1,8 млн, ніж у 2017 р. Кількість туристичних виїздів 3 Італії збільшилася $з 24$ млн у 2006 р. до 33,6 млн осіб у 2018 р., і зростала щорічно на $2,7 \%$. Отже, в Італії спостерігається позитивне сальдо туристичних потоків, що сприяє розвитку економіки країни (рис. 2).

Основними країнами-постачальниками туристів до Італії є Німеччина (21 \%), Франція (12 \%), Великобританія (8 \%), Австрія (7 \%), Швейцарія (6\%). Провідні місця з прийому іноземних туристів займають такі міста, як Венето, Тоскана, ТрентіноАльто-Адідже. У 2018 р. італійці найбільше подорожували до Франції (23 \%), Іспанії (13\%), Великобританії (6 \%), Німеччини (5 \%), Греції (4 \%) (Italy 2019 Annual Research, 2019). Туристичні потоки між Італією та Україною $є$ незначними. За даними Адміністрації Держприкордонслужби України, у
2018 р. нашу державу відвідало 97,6 тис. громадян Італії, тоді як виїзд громадян України до Італії склав 287,3 тис. осіб (Information on foreign visits of Ukraine and departure of Ukrainian citizens abroad (2015-2018), 2020).

За даними Національного інституту статистики Італії (ISTAT), у 2018 р. резидентами Італії здійснено 78,9 млн поїздок із ночівлею, що на 19,5\% більше, ніж у 2017 р. Середня тривалість поїздок склала 5,5 ночей. Що стосується напрямків подорожей, то на внутрішні поїздки припадає 79,3 \%, тоді як виїзні - 20,7 \%. Виїзні поїздки спрямовані переважно до країн Європи. 13,1 \% жителів Італії провели свої літні відпустки в регіоні Апулія та 9,9 \% - в Емілії-Романьї, тоді як регіон Трентіно-Альто-Адідже був основним місцем відпочинку взимку (31 \%), Ломбардія восени $(14,2 \%)$ та Тоскана навесні (14,1 \%) (Trips and holidays in Italy and abroad, 2020). 
У 2018 р. туризм приніс Італії прибуток у розмірі 49,3 млрд дол. США й висуває країну на шосте місце у світі та четверте - у Європі (рис. 3) (World Travel and Tourism). Динаміка доходів від міжнародного туризму протягом 2006-2018 pp. має циклічний характер, що зумовлено їх зростанням і спадами. Протягом останніх років спостерігається збільшення доходів від міжнародного туризму (рис. 3).

Італія відзначається територіальними диспропорціями у соціально-економічному розвитку. Значна диференціація спостерігаються у рівнях соціально-економічного розвитку Півночі та Півдня, що зумовлено історичними особливостями розвитку цих макрорегіонів країни. Туристичний розвиток регіонів Італії характеризується також значною територіальною нерівномірністю, що зумовлено соціально-економічними, природно-географічними та історичними чинниками. Тому для виявлення територіальних особливостей розвитку туризму в Італії проведено оцінку рівня туристичного розвитку регіонів країни (табл. 1).

Аналіз інтегрального індексу $(I)$ показав значну територіальну нерівномірність у рівнях туристичного розвитку регіонів Італії. За цим показником регіони країни згруповано в шість груп: із високим, вищим від середнього, середнім, нижчим від середнього, низьким і дуже низьким рівнем (рис. 4).

Найвищий рівень розвитку туризму в Італії мають регіони Венето й Трентіно-Альто-Адідже, які розміщені в Північно-Східній Італії. Ці регіони мають розвинену туристичну інфраструктуру, тут спостерігається найбільша концентрація закладів розміщення туристів, характерні найвищі показники забезпеченості колективними закладами розміщення (понад 120 закладів на 10000 осіб) та висока кількість туристичних прибуттів (понад 10 млн). Регіон Венето, центром якого $\epsilon$ всесвітньо відоме місто Венеція, $\epsilon$ найбільш туристично розвиненим регіоном Італії (табл. 1). Венеція є другим після Риму містом країни за кількістю туристичних прибуттів (12,1 млн у 2018 р.). У Венето знаходиться найбільша кількість готелів та інших закладів розміщення туристів (72,4 тис. од.), a кількість туристичних прибуттів склала 19,6 млн (рис. 4). Регіон має потужний природноресурсний та історико-культурний потенціал. Тут знаходиться велика кількість лагун, в одній з яких розміщене м. Венеція, та озеро Гарда (східний берег «Рів'єра олив»). На території регіону простягаються Доломітові Альпи (провінція Беллуно), має вихід до Адріатичного моря, що дає можливість розвивати гірськолижний i купально-пляжний туризм. Найбільшими туристичними центрами регіону $\epsilon$ Венеція, Верона, Падуя, а також Беллуно, Тревізо й Ровіго (Sito ufficiale del turismo in Italia, 2020). Регіон має поліфункціональну туристичну спеціалізацію, де розвиваються такі види туризму, як гірськолижний (Кортіна-д’Ампеццо, Аллеге, Фалькаде, АуронцоКадоре, Дзольдо-Альто), лікувально-оздоровчий (термальні курорти Абано, Монтегротто й Теоло), пляжний (Єзоло, Бібіоне, Кавалліно, Каорле), екологічний, еногастрономічний (Бардоліно, Прамаджоре, Конельяно) та ін.
Трентіно-Альто-Адідже є одним із наймальовничіших регіонів Італії, насамперед завдяки гірським ландшафтам. За рівнем розвитку туризму він займаєдруге місцев Італії. Тутпрокладено сотні кілометрів гірськолижних трас і знаходиться велика кількість курортів (Мадонна-ді-Кампільйо, Канацеї, Моена, Сан Мартіно ді Кастроцца, Корвараін-Бадія, Ортізеї). Регіон має найвищий коефіцієнт завантаженості (65 \%) та використання спальних місць (61 \%) закладів розміщення туристів (табл. 1). Лікувально-оздоровчий туризм розвивається на базі термальних курортів Терме-ді-Левіко, Термеді-Мерано, Пеїо, Раббі й Комано-Терме та ін. Через територію регіону Трентіно-Альто-Адідже проходять еногастрономічні маршрути. Регіон відомий сортом винограду - піно неро. Туристичними центрами $\epsilon$ Тренто, Роверето, Ріва-дель-Гарда, Больцано, Мерано, Брессаноне (Sito ufficiale del turismo in Italia, 2020).

До групи регіонів із вищим від середнього по країні рівнем туристичного розвитку належать області Північно-Східної та Центральної Італії - Лаціо, Емілія-Романья і Тоскана (рис. 4). Для них характерні високі показники кількості (понад 15 тис. од.), місткості (загалом 1,4 млн місць), територіальної концентрації закладів розміщення туристів, кількості туристичних прибуттів (понад 11 млн). Регіони мають вихід до Адріатичного (Емілія-Романья), Тірренського (Тоскана, Лаціо) й Лігурійського (Тоскана) морів. Зважаючи на це, на прибережних територіях регіонів розміщені численні морські курорти: Ріміні, Річчоне й Каттоліка (Емілія-Романья), курортна зона Версилія (Тоскана), острови Тосканського архіпелагу, Гаета, Сабаудія, Сан-Феліче-Чирчео, Сперлонга та острови Понца й Вентотене (Лаціо). Варто відзначити, що регіони відомі своїми термальними курортами: Рим (Терми Каракалли), Тіволі в регіоні Лаціо, СальсомаджореТерме, Баньйо-ді-Романья у регіоні ЕміліяРоманья, Монтекатіні, Сатурнія, Монтепульчано, Монсуммано-Терме в Тоскані (Sito ufficiale del turismo in Italia, 2020). Загалом оздоровчий туризм відіграє важливе значення для туристичного розвитку цих регіонів. Регіони мають також потужний історикокультурний потенціал. Тут знаходиться багато пам'яток світової спадщини ЮНЕСКО, зокрема Колізей, історичний центр міст Рим, Флоренція і Сан-Джиміньяно, ренесансне місто Феррара та дельта р. По, ранньохристиянські пам'ятники в м. Равенна, вілла Адріана в Тіволі та ін. Розвитку набув також релігійний туризм. Екотуризм розвивається на базі розгалуженої мережі національних природних парків i заповідників, серед яких Тосканський архіпелаг, Чірчео, Форесте Казентінезе, Аппеніно Тоско-Еміліано, Монте Фальтерона та Кампінья та ін. Туристичними ценрами регіону Емілія-Романья є Болонья, Равенна, Ріміні, у Тоскані - Флоренція, Сієна, Піза, у Лаціо - Рим, Рієті, Вітербо, Латіна.

Середній рівень розвитку туризму мають Ломбардія, Кампанія, Валле-д’Аоста й Лігурія, які розміщені на півночі та півдні Італії (рис. 4). Для них притаманні середні показники розвитку туризму (табл. 1). У регіонах Ломбардія, Валле-д’Аоста, 


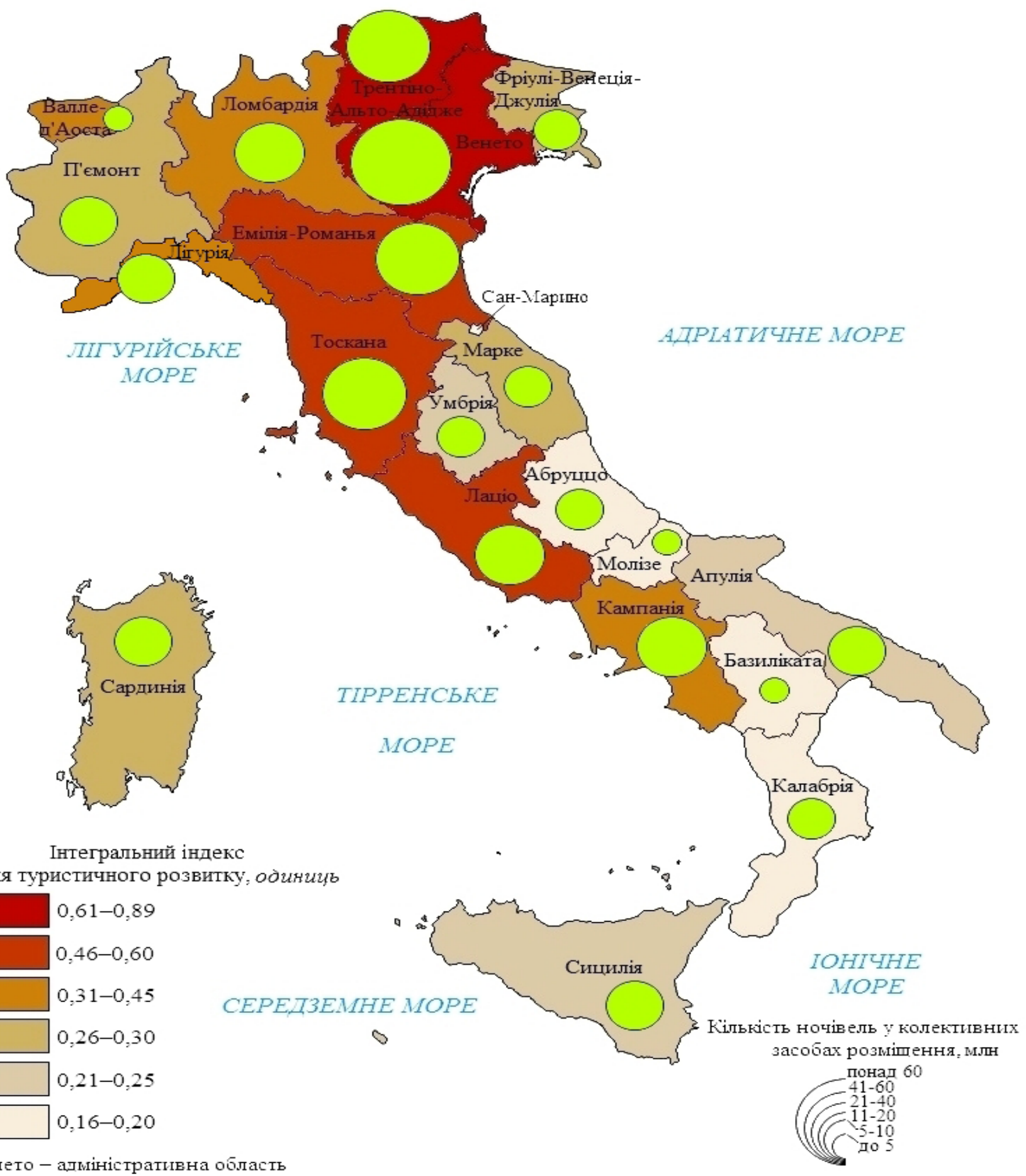

Рис. 4. Туристичний розвиток регіонів Італії у 2018 р.

Лігурія активно розвивається гірськолижний туризм та альпінізм. Відомими гірськолижними курортами є Тонале, Борміо, Лівіньо, Мадезімо (Ломбардія), Курмайор, Брей-Червінія, Піла (Валле-д’Аоста), Монесі, Санто-Стефано-д’Авето (Лігурія). У регіоні Валле-д’Аоста знаходиться найвища вершина Європи - г. Монблан $(4810$ м). У Кампанії розвивається купально-пляжний туризм, оскільки регіон має вихід до Тірренського моря, оздоровчий туризм (острови Іскія, Капрі). Кампанія є одним із найбільш розвинених регіонів не тільки Південної Італії, але й всієї країни. Регіон Лігурія відомий також своїм узбережжям, яке має назву «Лігурійська Рив'єра». Уздовж цього узбережжя простяглися курорти: Портофіно, Санта-Маргерита-Лігуре, Рапалло, Сестрі-Леванте та ін. Цікавими туристичними об'єктами в цих регіонах є озера Гарда, Комо й Маджоре, вулкан Везувій. Туристичними центрами регіонів є Мілан, Комо, Неаполь, Салерно, Генуя, Сан-Ремо (Sito ufficiale del turismo in Italia, 2020).

Нижчим від середнього по Італії рівнем розвитку туризму відзначаються такі регіони, як Марке, Сардинія, Фріулі-Венеція-Джулія, П'ємонт (рис. 4). Для цих регіонів характерна незначна кількість 
закладів розміщення та невисокий коефіцієнт їх завантаженості (менше 50 \%). Регіони мають вихід до Адріатичного (Фріулі-Венеція-Джулія, Марке), Тірренського й Середземного (Сардинія) морів. Ці регіони мають вдале поєднання природних та історико-культурних рекреаційних ресурсів, що дає змогу розвивати різні види туризму. Гірськолижний туризм розвивається в П'ємонті, Фріулі-ВенеціїДжулії, Марке. Лікувальні-оздоровчий туризм на базі термальних джерел набув розвитку в П'ємонті i Фріулі-Венеції-Джулії. Відомими термальними курортами є Акві-Терме й Терме-ді-Градо. В області Марке та на о. Сардинія розвинутий купальнопляжний туризм. Туристичними центрами регіонів цієї групи є Турін, Кераско, Альба, Івреа в П'ємонті, Трієст, Аквілея, Горіція, Уніде, Порденоне у ФріуліВенеції-Джулії, Кальярі, Сассарі на о. Сардинія, Асколі-Пічено, Анкона, Урбіно в регіоні Марке (Sito ufficiale del turismo in Italia, 2020).

Для регіонів Сицилія, Апулія, Умбрія характерний низький рівень розвитку туризму, що обумовлено невисокими показниками соціальноекономічного розвитку, низькою територіальною концентрацією та завантаженістю (менше 40 \%) колективних засобів розміщення, незначною кількістю туристичних прибуттів (табл. 1). Одним 3 основних видів туризму на Сицилії та в Апулії $\epsilon$ купально-пляжний туризм, оскільки ці регіони мають сприятливі кліматичні умови, вихід до морів. Центральний регіон Італії - Умбрія вирізняється поєднанням високоякісних історико-культурних та природних туристичних ресурсів, що $є$ базою для розвитку культурно-пізнавальних та активних видів відпочинку. Найбільш цікавими туристичними об'єктами є діючий вулкан Етна, м. Сіракузи, Долина храмів на о. Сицилія, Базиліка Сан-Франческо, Тразіменське озеро, водоспад Марморе в Умбрії, Базиліка святого Миколая Чудотворця, замок Кастель-дель-Монте в Апулії. Основними туристичними центрами регіонів є Ассізі, Терні, Перуджа (Умбрія), Палермо, Мессіна, Сіракузи, Катанія (о. Сицилія), Барі, Таранто, Галліполі, Фодджа (Апулія).

Південні регіони Італії, такі як Абруццо, Базиліката, Молізе й Калабрія мають дуже низький рівень розвитку туризму (рис. 4). Вони відзначаються низькими показниками кількості, концентрації, завантаженості колективних засобів розміщення та кількості туристичних прибуттів (табл. 1). Ці регіони мають найнижчі рівні соціально-економічного розвитку в країні, що зумовило низький рівень розвитку туристичної галузі. Тут розвиваються такі види туризму, як гірськолижний (Абруццо, Молізе), екологічний, купально-пляжний, культурний. Туристичними центрами регіонів є міста Аквіла, Пескара, Терамо (Абруццо), Кампобассо, Ізернія (Молізе), Реджо-ді-Калабрія, Вібо-Валентія,
Козенца, Катандзаро (Калабрія), Потенца, Матера (Базиліката).

Отже, найбільш туристично розвиненими макрорегіонами Італії $€$ Північно-Східний, Центральний та Північно-Західний (табл. 1). Тоді як південні регіони Італії мають низький рівень розвитку туризму. Найбільша диверсифікація туристичного продукту спостерігається в Сицилії, Сардинії, Ломбардії, Північно-Східному макрорегіоні. Перші два регіони використовують для розвитку туризму свій природно-рекреаційний потенціал, але поступаються іншим регіонам за рівнем соціально-економічного розвитку. Ломбардія і Північний Схід Італії мають розвинену інфраструктуру, спрямовану на ефективне використання культурно-історичних ресурсів. Деякі південні регіони Італії пропонують на міжнародному туристичному ринку тільки одиндва види відпочинку, так як це найменш економічно розвинені регіони країни, і вони орієнтовані, перш за все, на внутрішній ринок (Shahnovich, 2015).

Аналіз територіальних особливостей розвитку туризму в регіонах Італії показав, що існує значна залежність між рівнями соціально-економічного та туристичного розвитку. Для підтвердження цієї залежності розраховано коефіцієнти кореляції між показниками індексу рівня туристичного розвитку та ВВП і ВВП на душу населення. Так, помітна залежність існує між рівнем туристичного розвитку та показником ВВП регіонів Італії. Коефіцієнт кореляції становить $0,65\left(\mathrm{t}_{\mathrm{st}}=3,66 ; \mathrm{p}_{<0.05}=0,002\right)$. Висока залежність спостерігається між показником ВВП на душу населення 3 коефіцієнтом кореляції - 0,75 $\left(\mathrm{t}_{\mathrm{st}}=4,83 ; \mathrm{p}_{<0.05}=0,0001\right)$.

Висновки. Проведений аналіз розвитку туризму в Італії показав, що визначальними особливостями сучасного туристичного розвитку країни є: щорічне зростання кількості туристичних прибуттів; значні обсяги надходжень від туристичної галузі; позитивне сальдо туристичних потоків; висока частка туризму у ВВП країни; формування всесвітньовідомих осередків туризму; високі туристичні показники. Все це свідчить про те, що Італія є одним із туристичних лідерів на міжнародному туристичному ринку. Геопросторовий аналіз туристичного розвитку Італії засвідчив, що найбільша інтенсивність туристичних прибуттів спостерігається в альпійських регіонах країни, які спеціалізуються на гірськолижному туризмі. Високий рівень розвитку туризму характерний також для північних та центральних регіонів країни. Найнижча інтенсивність туризму спостерігається в південно-східних регіонах країни. Перспективи подальших досліджень пов'язані 3 аналізом проблем та перспектив розвитку туризму в Італії та їі регіонах. 


\section{References:}

1. Ahafonova, L. G., \& Ahafonova, O. Ye. (2002). Tourism, hotel and restaurant business: pricing, competition, government regulation. Kyiv, Znannia Ukraiiny. [In Ukrainian]. [Агафонова Л. Г., Агафонова О. С. Туризм, готельний та ресторанний бізнес: ціноутворення, конкуренція, державне регулювання : навч. посіб. К.: Знання України, 2002. 358 с.]

2. Berrino, A. (2011). Storia del turismo in Italia. Bologna, II Mulino.

3. Bezuhlyi, V. V. (2011). Prerequisites for the development of cognitive tourism in Italy. Geography and Tourism, 16, 43-51. [In Ukrainian]. [Безуглий В. В. Передумови розвитку пізнавального туризму в Італії // Географія та туризм. 2011. Вип. 16. С. 43-51.]

4. Capacity of collective accommodation establishments and occupancy in collective accommodation establishments. Retrieved from: http://dati.istat.it/Index.aspx?QueryId=7053\&lang=en.

5. Doan, P. V. (2014). Sustainable development of local tourist systems and regions of Italy. Geography and Tourism, 31, 15-29. [In Ukrainian]. [Доан П. В. Сталий розвиток локальних туристичних систем і регіонів Італії // Географія та туризм. 2014. Вип. 31. С. 15-29.]

6. Eurostat (2020). Retrieved from: https:/lec.europa.eu/eurostat/ web/tourism/data/database.

7. Honcharenko, Ya. Ye., \& Shykina, O. V. (2018). Trends in the development of hotel industry in Italy. In $A c-$ counting and analytical support for innovative transformation of Ukrainian economy: proceedings of the XIIth AllUkrainian scientific and practical conference (Odessa, May 31 - June 1, 2018) (pp. 202-205). Odesa, ONPU. [In Ukrainian]. [Гончаренко Я. Є., Шикіна О. В. Тенденції розвитку готельної індустрії Італії // Обліково-аналітичне забезпечення інноваційної трансформації економіки України : матеріали XII Всеукраїнської науковопрактичної конференції (м. Одеса, 31 травня-1 червня). Одеса: ОНПУ, 2018. С. 202-205.]

8. Information on foreign visits of Ukraine and departure of Ukrainian citizens abroad (2015-2018). Retrieved from: https://me.gov.ua/Documents/Download?id=82f4f7d1-0860-49d3-b2b5d0fe365cd 886. [In Ukrainian]. [Інформація щодо відвідування України іноземцями та виїзду громадян України за кордон (2015-2018 рр.). Режим доступу: https://me.gov.ua/Documents/Download?id=82f4f7d1-0860-49d3-b2b5-d0fe365cd886.]

9. Istituto Nazionale di Statistica (2020). Retrieved from: https://www.istat.it.

10. Italy 2019 Annual Research: key highlights (2019). Retrieved from: https://www.wttc.org/economic-impact/ country-analysis/country-data.

11. Italy. Tourism (2020). Retrieved from: https://knoema.com/ atlas/Italy.

12. Jelardi, A. (2012). Storia del viaggio e del turismo in Italia. Milano: Mursia.

13. Klapchuk, M. V. (2017). Tourism resources of Italy as a basis for tourism development. In Strategy of investment and innovative development of Ukrainian economy in the conditions of globalization: state and ways of formation: collection of materials of international scientific-practical conference (Lviv, March 23, 2017) (pp. 103-110). Lviv, LIET. [In Ukrainian]. [Клапчук М. В. Туристичні ресурси Італії, як основа для розвитку туризму // Стратегія інвестиційно-інноваційного розвитку економіки України в умовах глобалізації: стан та шляхи становлення: зб. матер. міжнар. наук.-практ. конф. (м. Львів, 23 березня 2017 р.). Львів: ЛІЕТ, 2017. С. 103-110.]

14. Patiychuk, V. O. (2016). Italy as an international center for orthodox religious and pilgrimage tourism. Scientific bulletin of Lesya Ukrainka Eastern European National University. Series: Geographical Sciences, 15(340), 86-93. [In Ukrainian]. [Патійчук В. О. Італія як міжнародний центр православного релігійно-паломницького туризму // Науковий вісник Східноєвропейського національного університету ім. Лесі Українки. Серія: Географічні науки. 2016. № 15 (340). C. 86-93.]

15. Patiychuk, V., \& Lukashuk, O. (2017). The main orthodox religious and pilgrimage centers in Italy. International relations, public communications and regional studies, 2, 54-66. [In Ukrainian]. [Патійчук В., Лукашук О. Основні православні релігійно-паломницькі центри Італії // Міжнародні відносини, суспільні комунікації та регіональні студії. 2017. № 2. С. 54-66.]

16. Shahnovich, I. A. (2015). Tourism development in Italy regions. In XXI century demographic risks: (on World Population Day): proceedings of the II interuniversity student seminar, May 14, 2015 (pp. 168-171). [In Russian]. [Шахнович И. А. Развитие туризма в регионах Италии // Демографические риски ХХІ века: (к Международному дню народонаселения): материалы II Межвузовского студенческого семинара, 14 мая 2015 г. 2015. С. 168-171.]

17. Sito ufficiale del turismo in Italia (2020). Retrieved from: http://www.italia.it/it/home.html.

18. Smal, V. V. (2013). Tourism in Italy: trends, challenges, ways of overcoming problems. Geography and Tourism, 24, 86-93. [In Ukrainian]. [Смаль В. В. Туризм в Італії: тенденції, виклики, шляхи подолання проблем // Географія та туризм. 2013. Вип. 24. С. 86-93.]

19. Schuka, H. P. (2010). Tourist characteristics of Italy. Geography and Tourism, 6, 122-125. [In Ukrainian]. [Щука Г. П. Туристська характеристика Італії // Географія та туризм. 2010. Вип. 6. С. 122-125.]

20. The Travel \& Tourism Competitiveness Report 2019 (2019). Retrieved from: https:/www.weforum.org/reports/ the-travel-tourism-competitiveness-report-2019.

21. Trips and holidays in Italy and abroad (2020). Retrieved from: https://www.istat.it/it/files//2019/02/Stat report_viaggi-e-vacanze_EN.pdf.

22. World Development Indicators (WDI) (2020). Retrieved from: http://datatopics.worldbank.org/world-development-indicators.

23. World Heritage List Statistics (2020). Retrieved from: https://whc.unesco.org/en/list/stat.

24. World Travel and Tourism (2020). Access mode: https://www.wttc.org.

25. Yunah, Yu. V. (2015). Comparative geographical analysis of tourism development in Italy regions. In $X X I$ century demographic risks: (on World Population Day): proceedings of the II interuniversity student seminar, May 14, 2015 (pp. 171-173). [In Russian]. [Юнах Ю. В. Сравнительно-географический анализ развития туризма в регионах Италии // Демографические риски XXI века: (к Международному дню народонаселения): материалы II Межвузовского студенческого семинара, 14 мая 2015 г. 2015. С. 171-173.] 